\title{
Changes in the activities of key enzymes of glycolysis during the cell cycle in yeast: a rectification
}

\author{
W. De Koning, ${ }^{*}$ K. Groeneveld, L. J. W. M. Oehlen, J. A. Berden and K. van Dam \\ EC Slater Institute for Biochemical Research and Biotechnological Center, University of Amsterdam, Plantage \\ Muidergracht 12, NL-1018 TV Amsterdam, The Netherlands
}

(Received 13 August 1990; revised 14 November 1990; accepted 17 December 1990)

\begin{abstract}
Activities of glycolytic enzymes were determined in elutriation fractionated cultures of Saccharomyces cerevisiae grown on different carbon sources. Almost pure fractions of single cells at the G1 stage of cell division were obtained for some of the growth conditions tested, whereas other stages were enriched in particular fractions. Specific activities of glucose-6-phosphate dehydrogenase and alcohol dehydrogenase were found to be constant during the cell cycle, as reported by van Doorn et al. (1988a), Journal of Bacteriology 170, 4808-4815, and $(1988 b)$, Journal of General Microbiology 134, 785-790. In contrast to the earlier reports, the activities of hexokinase, phosphofructokinase, pyruvate kinase and trehalase were also constant in different stages of the cell cycle. For hexokinase and phosphofructokinase it was shown that the apparent specific activity in a cell-free extract strongly diminished when extracts contained less than $0.5-1 \mathrm{mg}^{-1}$ protein $\mathrm{ml}^{-1}$. In the experiments of van Doorn et al. (1988a) the protein content of the outer fractions was up to 20 times lower than that of the central fractions, suggesting an alternative explanation for the observed changes in enzyme activities during the cell cycle. Therefore, we want to rectify the observations presented by van Doorn et al. $(1988 a)$, and conclude that the activities of the glycolytic enzymes do not vary greatly during the cell cycle of $S$. cerevisiae.
\end{abstract}

\section{Introduction}

Although growth of baker's yeast on glucose and other $\mathrm{C}_{6}$ carbon sources has been studied extensively (for a review see Gancedo \& Serrano, 1989), many aspects of the regulation of glucose metabolism are incompletely understood. Depending on the conditions used in the experiments, hexokinase (HK), phosphof ructokinase (PFK), pyruvate kinase (PK) and glucose transport have been considered as steps that have a large control over the flux. For most of these glycolytic enzymes one or more mechanisms that control the activity of the enzyme have been established in vitro. For example, PFK activity was found to be influenced by (amongst others) $\mathrm{NH}_{4}^{+}$, phosphate, AMP and fructose 1,6-bisphosphate (Sols, 1981). Previous studies in our laboratory showed that the in vitro specific activity of these enzymes varied greatly when cells in different stages of the cell cycle were assayed. Using elutriation fractionation, a greatly re-

\footnotetext{
Abbreviations: PMSF, phenylmethylsulphonyl fluoride; $\mathrm{KP}_{\mathrm{i}}$, potassium phosphate buffer; HK, hexokinase; PFK, phosphofructokinase; PK, pyruvate kinase; ADH, alcohol dehydrogenase; G6PDH, glucose6-phosphate dehydrogenase.
}

duced in vitro activity of several glycolytic enzymes was observed in the G1 phase (van Doorn et al., 1988a). A similar change in activity was also observed for trehalase in a synchronously growing culture. This change could be eliminated by preincubation of the cell extract with a cAMP-dependent protein kinase, suggesting a dephosphorylation of the protein at the start of the G1 phase to be the cause of the observed fluctuations in specific activity (van Doorn et al., 1988b). The mechanism for these changes in activity of the glycolytic enzymes has not been clarified. Studies with partly synchronized continuous cultures have shown significant changes in $\mathrm{CO}_{2}$ production and $\mathrm{O}_{2}$ consumption during the cell cycle (Küenzi \& Fiechter, 1969). Although such results are not directly transferable to undisturbed, exponentially growing cultures they indicate that the flux through the glycolytic pathway is different in the various growth stages. From these results it seemed reasonable to propose that models describing the flux through glycolysis should include the cyclic changes of enzyme activities during the cell cycle, thus making them much more complicated.

This paper shows that the previously reported changes in enzyme activity were mainly due to differences in the 
concentration of cells during extraction. When constant amounts of cell material were taken from all fractions, representing different stages of the cell cycle, no significant changes in the specific activities of glycolytic enzymes were observed, whether the cells were grown on glucose or on maltose or ethanol.

\section{Methods}

Organisms and cultivation. Saccharomyces cerevisiae strain DLI was grown on YEPD $[2 \%(\mathrm{w} / \mathrm{v})$ glucose, $2 \%(\mathrm{w} / \mathrm{v})$ peptone, $1 \%(\mathrm{w} / \mathrm{v})$ yeast extract] and $S$. cerevisiae strain Y185.1 (Creanor et al., 1983) on Yeast Nitrogen Base (Difco) supplemented with maltose $(0.5 \%)$ or ethanol $(1 \%, v / v)$. Cells were cultivated at $28^{\circ} \mathrm{C}$ in a rotary incubator at 180 r.p.m. for at least 20 generations in exponential phase and harvested at a density of $3-5 \times 10^{6}$ cells $\mathrm{ml}^{-1}$.

Elutriation. Elutriation was performed as described by van Doorn $e t$ al. (1988a), except that a single $40 \mathrm{ml}$ rotor cell was used. A Masterflex model 6523 (Cole Parmer Company, Chicago, USA) equipped with two pumpheads (pulsing out of phase) with tubing 16 was used to obtain the desired flow through the rotor. Pelleting of cells at the bottom of the chamber was prevented by using a small amount of Maxidens (Nycomed, Oslo, Norway) at the bottom (approx. $0.5 \%$ of the chamber volume).

Routinely, fractionation experiments were done at $2{ }^{\circ} \mathrm{C}$ using $20 \mathrm{~mm}$ potassium phosphate buffer $\left(\mathrm{KP}_{\mathrm{i}}\right) \mathrm{pH} 6$ for elutriation. The culture was cooled quickly in ice/water, sonicated for $20 \mathrm{~s}$ (in 0.5 litre portions) and pumped into the rotor cell, spinning at 4500 r.p.m., at a flowrate of

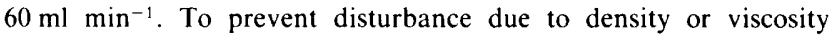
changes the last part of the culture was gradually mixed with elutriation buffer. After simultaneous decrease of flow rate and spinning speed to the preset values, fractionation was performed by stepwise increase of the flow rate as indicated for the different experiments. Fractions of $400 \mathrm{ml}$ were collected and a suitable part was concentrated on $1.2 \mu \mathrm{m}$ membrane filters $(25 \mathrm{~mm}$ diam., $1.2 \mu \mathrm{m}$ pore size). Cells were resuspended in $1 \mathrm{ml} \mathrm{KP_{i }} \mathrm{pH} 6$ in an Eppendorf tube, pelleted, frozen in liquid nitrogen and stored at $-70^{\circ} \mathrm{C}$.

Cells were counted and studied morphologically as described previously (van Doorn et al., 1988a).

Preparation of cell-free extract and enzyme assays. Extract was prepared by vortexing (2200 r.p.m.) with acid-washed glass beads at $4{ }^{\circ} \mathrm{C}$ on a Ika Vibrax VXR (Janke \& Kunkel). On the basis of relative cell volume (calculated from the flow rate) and cell number, it was calculated how much of the frozen pellet should be used for the extraction procedure to obtain a similar protein content in each fraction. A linear relation between relative cell volume and protein content was assumed (Oehlen et al., 1990). The calculated portion of the cells was resuspended in $200 \mu \mathrm{l}$ disruption buffer $\left(20 \mathrm{mM}-\mathrm{KP}_{\mathrm{i}}, \mathrm{pH} 7 \cdot 0\right.$, $50 \mathrm{mM}-\mathrm{NaF}$ ) and added to $0.7 \mathrm{ml}$ Eppendorf tubes containing $200 \mathrm{mg}$ glass beads $(0.45 \mathrm{~mm})$. Directly after disruption, $0.25 \%(\mathrm{v} / \mathrm{v})$ of $400 \mathrm{~mm}$-PMSF solution dissolved in dimethyl sulphoxide was added and cell debris was removed by centrifugation for $10 \mathrm{~min}$ in an Eppendorf centrifuge.

Enzyme activities were determined spectrophotometrically at $340 \mathrm{~nm}$ and $30^{\circ} \mathrm{C}$. Pyruvate kinase was assayed in $100 \mathrm{~mm}$-potassium phosphate $\mathrm{pH} 6.0$, containing $\mathrm{MgSO}_{4}, 30 \mathrm{~mm}$; phosphoenolpyruvate, $5 \mathrm{~mm}$; ADP, $2 \mathrm{~mm}$; fructose 1,6-bisphosphate, $1 \mathrm{~mm}$; NADH, $0.15 \mathrm{~mm}$; lactate dehydrogenase, $1.4 \mathrm{U}$. Phosphof ructokinase was measured in $50 \mathrm{~mm}$-Tris $/ \mathrm{HCl}, \mathrm{pH} 7.2$, according to Hofmann \& Koppersläger (1982). Hexokinase was measured in 50 mM-triethanol- amine $/ \mathrm{HCl} \mathrm{pH} 7 \cdot 6$, containing $\mathrm{MgSO}_{4}, 10 \mathrm{~mm} ; \mathrm{ATP}, 1 \mathrm{~mm}$; NADP+, $0.4 \mathrm{~mm}$; glucose-6-phosphate dehydrogenase, $0.6 \mathrm{U}$; phosphoglucose isomerase, $1 \mathrm{U}$ and fructose, $10 \mathrm{~mm}$. Glucose-6-phosphate dehydrogenase and alcohol dehydrogenase were measured as described by Bergmeyer et al. (1974b). Trehalase activity was determined in $20 \mathrm{mM}-$ MOPS pH 6.8 containing PMSF, $1 \mathrm{~mm} ; \mathrm{NaF}, 50 \mathrm{mM} ; \mathrm{CaCl}_{2}, 2.5 \mathrm{~mm}$; trehalose, $20 \mathrm{mM}$. After $1 \mathrm{~h}$ the reaction was terminated by boiling the samples for $3 \mathrm{~min}$ and liberated glucose was determined as described by Bergmeyer $e t$ al. (1974a). For each sample a control was run without trehalose. All assays were tested for linearity with the quantity of extract. Usually analyses were performed on a Cobas Bio automatic analyser (Roche).

Protein was determined by means of the bicinchoninic acid reagent as described by the supplier (Sigma) using bovine serum albumin as a standard.

\section{Results}

Fractionation of $S$. cerevisiae Y185.1 grown on $0.5 \%$ maltose

Cells growing exponentially on maltose were fractionated according to cell size using the large elutriation cell as described in Methods. Fig. 1 ( $a$ ) shows the distribution of the different cell types. At flow rates up to $65 \mathrm{ml} \mathrm{min}^{-1}$ almost pure fractions of single cells were obtained. At higher flow rates, fractions were enriched in cells with a bud, whereas at the highest flow rates binucleate cells were more abundant. In contrast to the single cells, the latter types were not obtained as pure fractions.

Fig. $1(b, c)$ shows the in vitro activity of some enzymes involved in glucose metabolism as found in cell extracts from the different fractions. The ADH and G6PDH activities did not vary significantly in the various fractions, in accordance with the results obtained for $S$. cerevisiae DLl grown on YEPD by van Doorn et al. $(1988 a)$. However, in contrast to the earlier study no large changes in activity of PK were observed either, and for PFK and HK the differences in activities between the various fractions were much smaller than reported for strain DLl. Another feature that can be observed in Fig. $1(c)$ is the correlation between the patterns of HK activity and protein content. This might suggest that the observed changes are (partly) due to differences in protein content of the extracts.

\section{Fractionation of $S$. cerevisiae DLI grown on YEPD}

The differences in patterns of enzyme activities found in the present study for strain Y185.1 on maltose compared with previous findings for strain DL1 on YEPD, together with the possible effect of protein content of the extract on the activity of some enzymes, induced us to reinvestigate the results published by van Doorn et al. $(1988 a)$. In Fig. 2 the distribution of the different cell types and the activities of HK, PFK, ADH, PK, 

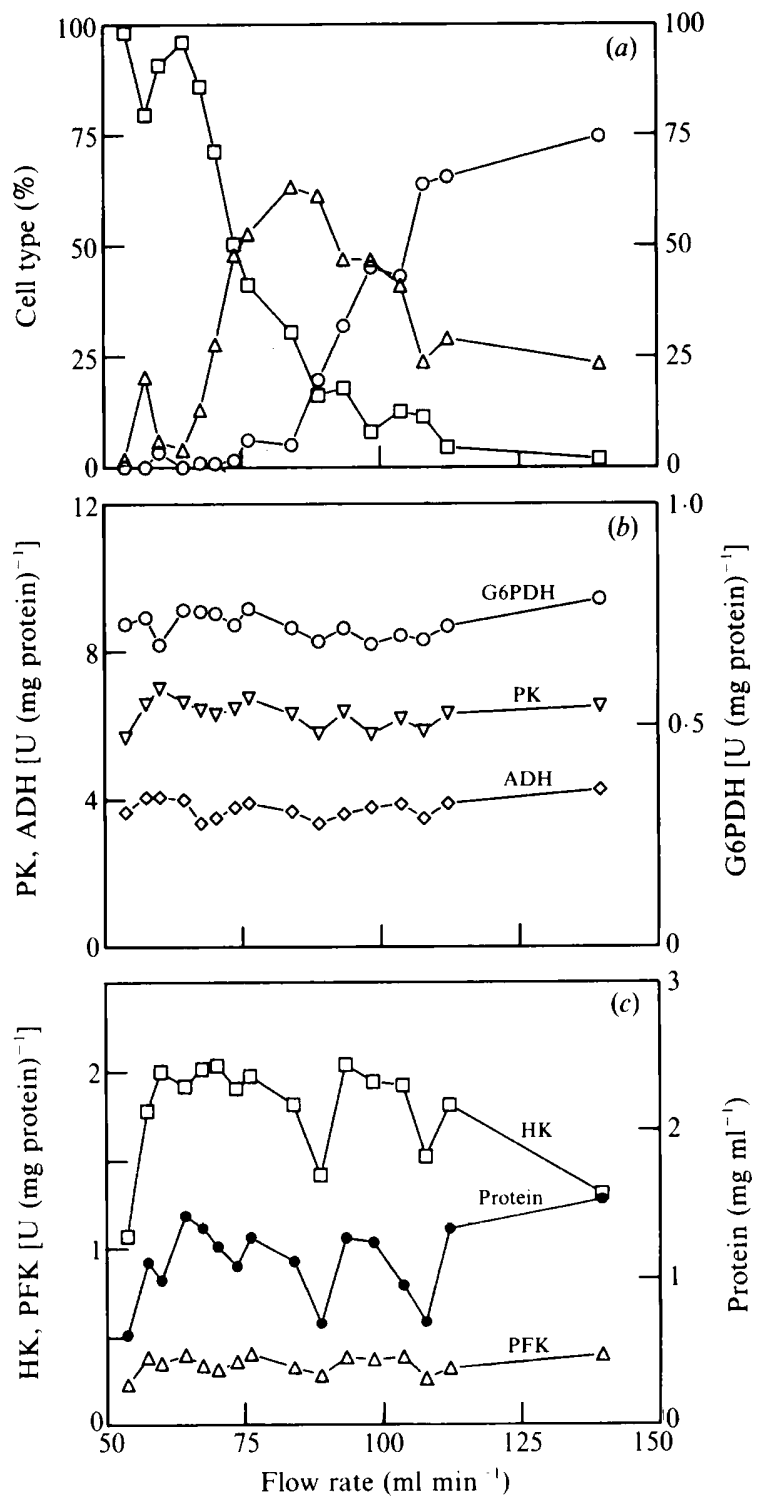

Fig. 1. Elutriation fractionation of $S$. cerevisiae Y185.1 grown aerobically on mineral medium containing $0.5 \%$ maltose. (a) Distribution of the different cell types over the fractions: $\square$, single cells; $\triangle$, cells with bud; $O$, binucleate cells. $(b, c)$ Activities [in $\mu \mathrm{mol} \mathrm{min}^{-1}(\mathrm{mg}$ protein $\left.\left.{ }^{-1}\right)\right]$ of pyruvate kinase (PK, $\nabla$ ), alcohol dehydrogenase (ADH, $\diamond)$, glucose-6-phosphate dehydrogenase (G6PDH, O), hexokinase $(\mathrm{HK}, \square)$ and phosphofructokinase (PFK, $\triangle$ ) in the different fractions. One unit $(\mathrm{U})$ is $1 \mu \mathrm{mol} \mathrm{min}{ }^{-1}$. In $(c)$ the protein content of the various samples is also plotted

G6PDH and trehalase in the different fractions after elutriation fractionation of strain DL1, grown on YEPD, are shown.

For G6PDH and PK only small, insignificant differences between the various fractions were observed. For the other enzymes a somewhat larger variation was measured, although the significance of the observed patterns may be disputed. In duplicate experiments (not
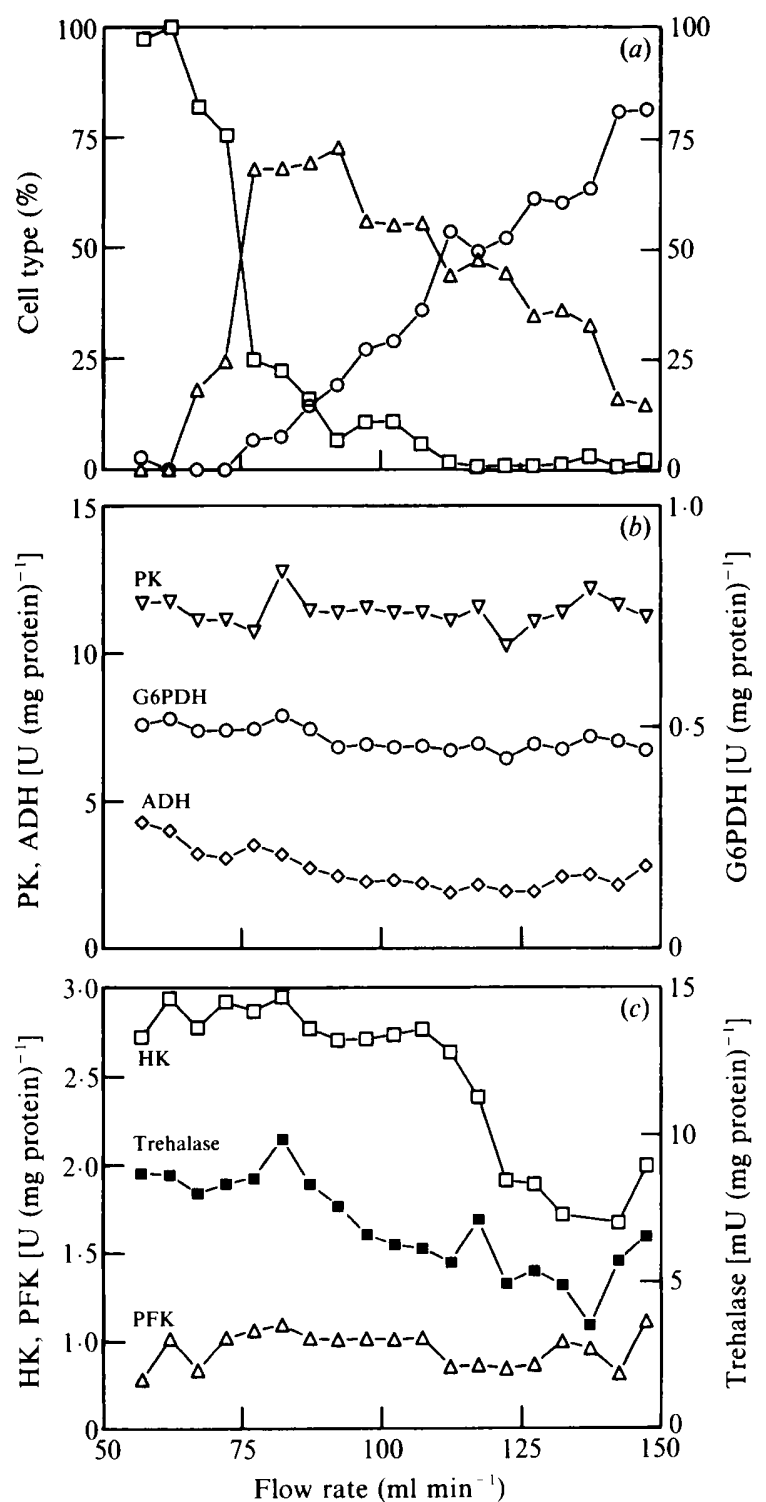

Fig. 2. Elutriation fractionation of $S$. cerevisiae DLI grown on YEPD. (a) Distribution of the different cell types over the fractions; $(b, c)$ enzyme activities. $\square$, Trehalase; the other symbols and units are as in Fig. 1.

shown) the patterns observed for these enzymes usually showed fluctuations of comparable magnitude, but without consistency between the duplicates. In no case did we find any clear evidence for a pattern as observed by van Doorn et al. $(1988 a)$.

\section{Effect of cell density at extraction on specific activity}

The similarity in the patterns for protein content and HK (and PFK) in Fig. 1 suggests that the protein content of the extract influences the specific activity. This relation was observed in most of the experiments. We therefore 


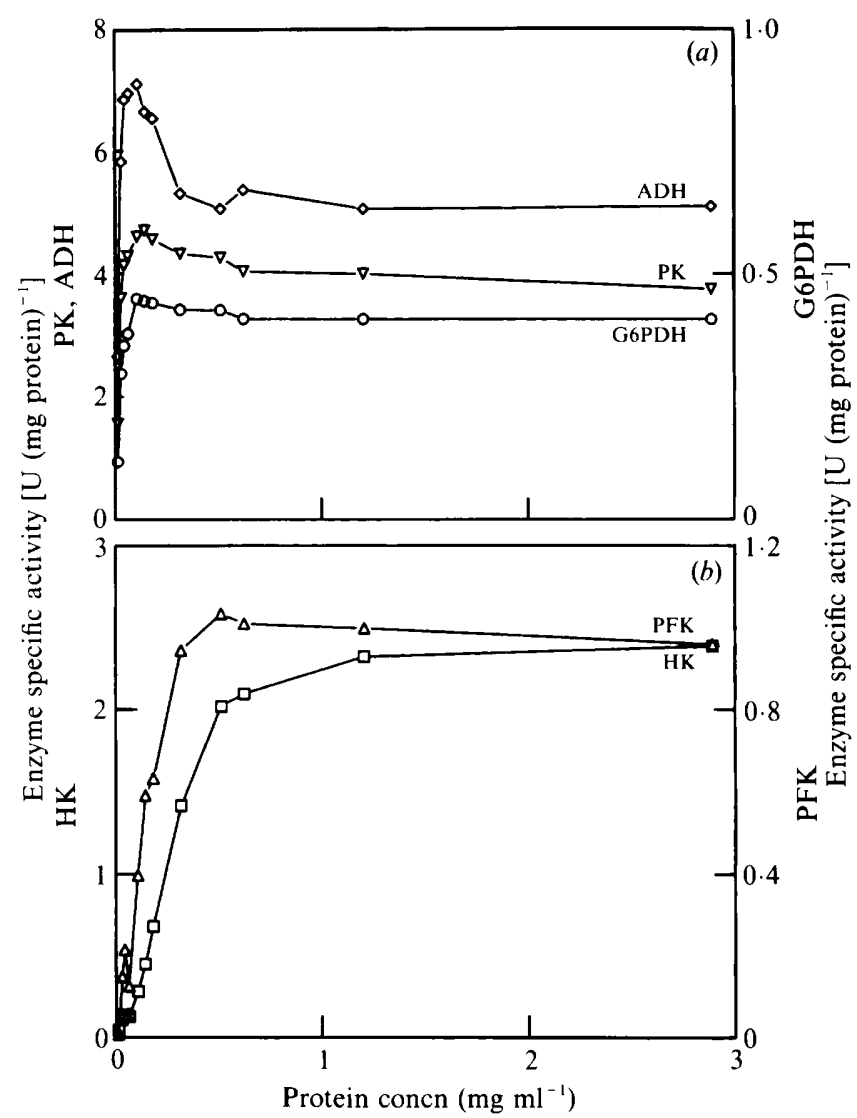

Fig. 3. Effect of preparing extracts at different cell densities on the specific activity of several glycolytic enzymes. Extracts were prepared from a series of dilutions of a concentrated cell suspension of $S$. cerevisiae DL1, grown on YEPD. Portions $(0.5 \mathrm{ml})$ of cell suspension were incubated with $0.5 \mathrm{~g}$ glass beads for $15 \mathrm{~min}$ in $1.5 \mathrm{ml}$ Eppendorf tubes at $4{ }^{\circ} \mathrm{C}$ on a Vibrax at 2200 r.p.m. Cell debris was removed by centrifugation $\left(10 \mathrm{~min}, 12000\right.$ r.p.m., $\left.4^{\circ} \mathrm{C}\right)$ and extracts were analysed on a Cobas Bio analyser (after appropriate dilution) for enzyme activities. Symbols and units are as in Fig. 1.

decided to investigate the relation between the cell density during extraction and the specific activity of some enzymes. The amount of protein extracted showed an almost linear relationship to the quantity of cells added; only at very low cell densities was somewhat less protein extracted (not shown). Extracts were diluted with extraction buffer to give approximately the same protein content in the assay. Fig. 3 shows the specific activities of HK, PFK, ADH, G6PDH and PK measured in the different extracts. For ADH and G6PDH the specific activity was nearly constant unless the extracts contained less than $0.05 \mathrm{mg}$ protein $\mathrm{ml}^{-1}$, whereas PK showed the highest specific activity around a protein content of $0 \cdot 1-$ $0.3 \mathrm{mg} \mathrm{ml}^{-1}$, and was virtually constant above $0.3 \mathrm{mg}$ protein $\mathrm{ml}^{-1}$; below $0.1 \mathrm{mg} \mathrm{ml}^{-1}$ the specific activity started to decrease. HK and PFK activities however, were reduced below $0.5-1 \mathrm{mg}$ protein $\mathrm{ml}^{-1}$ and were virtually zero at the lowest protein concentrations
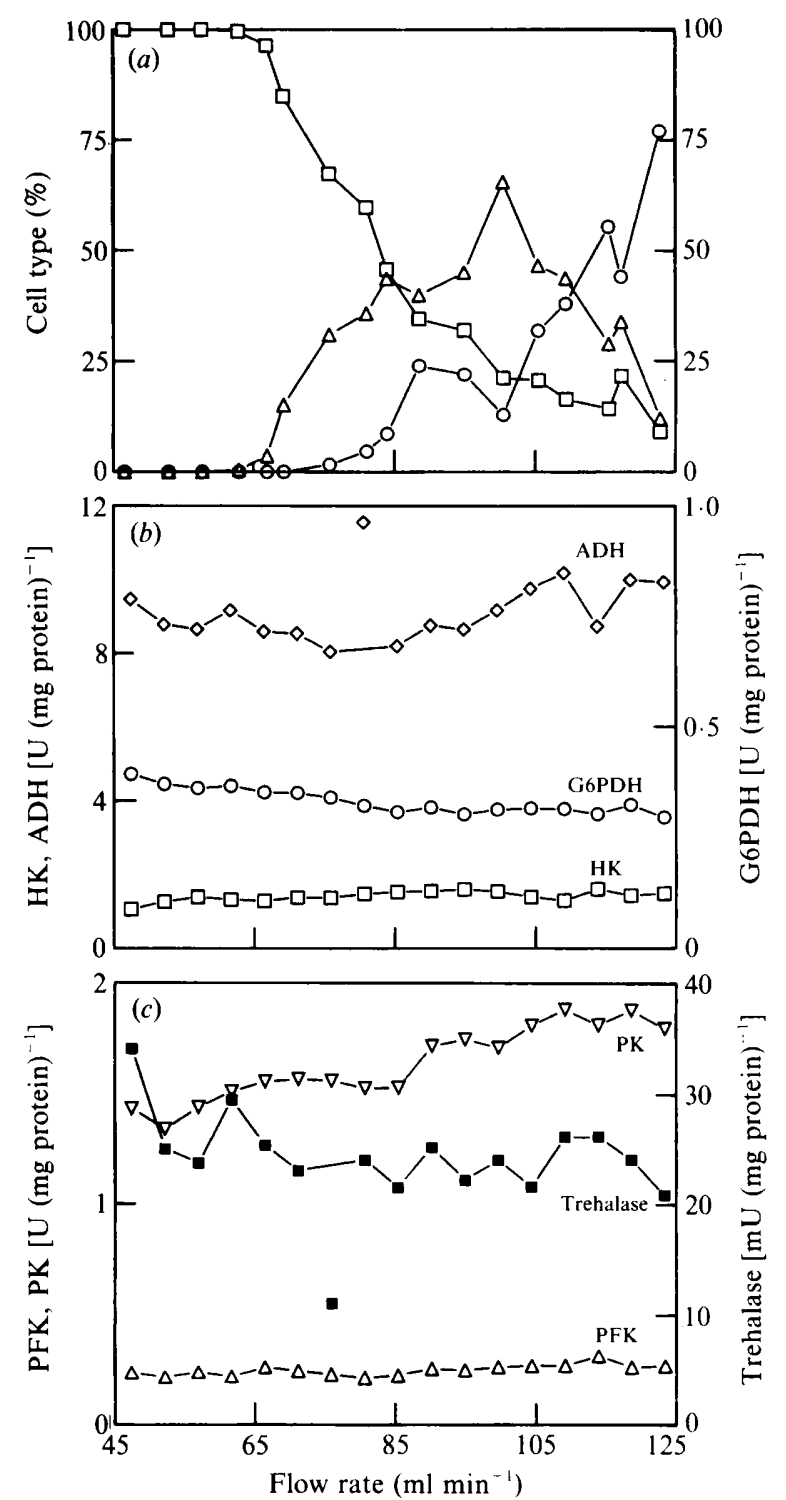

Fig. 4. Elutriation fractionation of $S$. cerevisiae Y185.1 grown aerobically on mineral medium containing $1 \%$ ethanol. (a) Distribution of the different cell types over the fractions; $(b, c)$ enzyme activities. Symbols and units are as in Figs 1 and 2.

investigated. This effect was caused by the extraction at low cell density and was not due to the dilution of the extract itself: dilution of a normal $\left(2 \mathrm{mg} \mathrm{ml}^{-1}\right)$ extract to a protein content of about $50 \mu \mathrm{g} \mathrm{ml}^{-1}$ in extraction buffer directly after the glass bead treatment did not influence the specific activity (not shown).

\section{Elutriation fractionation of ethanol-grown cells}

Although no important changes in the activity of glycolytic enzymes were observed after growth on glucose or maltose, we wished to investigate the possibility that changes occur under conditions where 
glycolysis is not active. We therefore decided to test strain Y185.1 grown on $1 \%$ ethanol. Growth on ethanol is slow and as a result the number of single (G1) cells was increased compared with growth on maltose (compare Fig. $4 a$ with Fig. 1a). The levels of most glycolytic enzymes were lower than during growth on maltose or glucose (Fig. 4b, c). Not surprisingly, ADH was increased significantly, as was trehalase. Large changes in activities during the cell cycle were, however, not observed.

\section{Discussion}

In most metabolic studies on yeast, effects of the cell cycle on metabolism have not been taken into account. The reason is presumably the experimental difficulty in obtaining sufficient cells at a certain stage of the cell cycle without applying an external stress. Experiments with synchronized continuous cultures, however, show that the flux through glycolysis is not constant during passage through the cell cycle (Küenzi \& Fiechter, 1969). Using elutriation fractionation it is possible to obtain samples from an exponentially growing culture enriched in a particular stage of the cell cycle (see Figs $1 a, 2 a$ and $4 a$ ). However, only G1 cells are obtained in an almost pure form; the other stages are always mutually contaminated, which can obscure possible changes.

The studies of van Doorn et al. $(1988 a, b)$ on cells fractionated by elutriation indicated that in an exponentially growing culture cells contain an enzymic machinery that is dependent on the cell cycle. The quantity of cells obtained was very low, especially in the outer fractions. Consequently, unless special precautions are taken, the outer fractions tend to contain (much) less protein than the fractions in the middle (as was observed in the crude data of van Doorn et al., 1988a). From Fig. 3 , it can be seen that the apparent specific activities of the enzymes HK and PFK were very sensitive to the amount of protein in the extract when protein contents fell below $0.5 \mathrm{mg} \mathrm{ml}^{-1}$. Although G6PDH and ADH were also influenced by the protein content, these enzyme activities were almost constant down to $0.05 \mathrm{mg}$ protein $\mathrm{ml}^{-1}$. The reason for the protein-dependent decrease in specific activity of $\mathrm{HK}$ and PFK is unknown but in a control experiment it was shown that dilution of the extract had no effect on the measured specific activity. Because it is quite unusual to prepare extracts with such a low protein content, further investigations on the background of this peculiar phenomenon were not undertaken.

The dependence of the specific activity on the concentration of cells during extraction probably ex- plains why the activities of the enzymes HK and PFK in the experiments of van Doorn et al. (1988a) appeared to change dramatically as a function of the cell cycle whereas those of ADH and G6PDH did not. For PK and trehalase the observed patterns are less easily explained, although PK sometimes showed an irreproducible behaviour and trehalase activity was low, making it very difficult to assay in dilute extracts. The pattern found by van Doorn et al. (1988b) for trehalase in synchronized cultures cannot be explained by differences in protein content. In those experiments, cells were lysed with lyticase and possibly small, unbudded cells may be somewhat more resistant to the lytic enzyme treatment. Prolonged incubation for the activation of trehalase by protein kinase presumably then resulted in total lysis of all samples. This might explain why trehalase, as it was assayed by van Doorn et al. (1988b), seemed to be activated by protein kinase treatment. Because of the low $\mathrm{pH}$ of the assay mixture, however, the vacuolar trehalase was measured in these experiments whereas only the cytosolic trehalase is activated by protein kinase (Londesborough \& Varimo, 1984).

In the elutriation experiments described in this paper, more cells per fraction were obtained by the use of a large elutriation cell and calculations were done to ensure that the protein content of the various fractions did not differ more than twofold. Under these conditions the specific activity of glycolytic enzymes was found to vary at most by a factor of two and the variations that showed up in a single experiment were not found in the repeats. The reason for these intra- and interexperimental variations is not known. Duplicate assays of the same extract on the Cobas Bio automatic analyser resulted, whenever tested, in differences of less than $2 \%$. All experiments were repeated at least twice. Taking averages of the repeats was not feasible, however, because the flow rate was not a set constant but was determined experimentally.

Preliminary results with synchronous cultures obtained by further cultivation of a single-cell fraction from an elutriation showed that under these conditions also large changes in activity are absent. We therefore conclude that the activities of HK, PK, PFK, trehalase, G6PDH and ADH do not vary to a large extent during the cell cycle of exponentially growing $S$. cerevisiae. However, due to the limited accuracy of the methods employed, more subtle cell-cycle-dependent differences in enzyme activities like the 'linear patterns' found by Creanor et al. (1983) cannot be excluded.

We are indebted to the Department of Electron Microscopy and Molecular Cytology, University of Amsterdam, for allowing us to use the Coulter counter facilities, and to the Department of Pediatrics, Academic Medical Center, University Hospital Amsterdam, for the use of the Cobas Bio automatic analyser. This work was supported partly by Gist-brocades NV, Delft, The Netherlands. 


\section{References}

Bergmeyer, H. U., Bernt, E., Schmidt, F. \& Stork, H. (1974a). Glucose. In Methods of Enzymatic Analysis, vol. 3, pp. 1196-1201. New York: Academic Press

Bergmeyer, H. U., Gawehn, K. \& Grassl, M. (1974b). Enzymes as biochemical reagents. Methods of Enzymatic Analysis, vol. 1, pp. 429459. New York: Academic Press.

Creanor, J., Elliott, S. G., Bisset, Y. C. \& Mitchison, J. M. (1983). Absence of step changes in activity of certain enzymes during the cell cycle of budding and fission yeasts in synchronous cultures. Journal of Cell Science 61, 339-349.

van Doorn, J., Valkenburg, J. A. C. Scholte, M. E., Oehlen, L. J. W. M., van Driel, R., Postma, P. W., Nanninga, N. \& van DAM, K. (1988a). Changes in activities of several enzymes involved in carbohydrate metabolism during the cell cycle of Saccharomyces cerevisiae. Journal of Bacteriology 170, 4808-4815.

van Doorn, J., Scholte, M. E., Postma, P. W. van Driel, R.\& van DAM, K. (1988b). Regulation of trehalase activity during the cell cycle of Saccaromyces cerevisiae. Journal of General Microbiology 134, 785-790

GanCEDo, C. \& SerRano, R. (1989). Energy-yielding metabolism. In The Yeasts, vol. 3, pp. 205-259. Edited by A. H. Rose \& J. S. Harrison. London: Academic Press.

Hofmann, E. \& KoppersläGer, G. (1982). Phosphofructokinase from yeast. Methods in Enzymology 90, 49-60.

KüENZI, M. T. \& FIEChTER, A. (1969). Changes in carbohydrate compositions and trehalase-activity during the budding cycle of Saccharomyces cerevisiae. Archives of Microbiology 64, 396-407.

Londesborough, J. \& Varimo, K. (1984). Characterization of two trehalases in baker's yeast. Biochemical Journal 219,511-518.

Oehlen, L. J. W. M., van Doorn, J., Scholte, M. E., Postma, P. W. \& VAN DAM, K. (1990). Changes in the incorporation of carbon derived from glucose into cellular pools during the cell cycle of Saccharomyces cerevisiae. Journal of General Microbiology 136, 413418 .

Sols, A. (1981). Multimodulation of enzyme activity. Current Topics in Cellular Regulation 19, 77-101. 